3. The official site of TROUW NUTRITION UKRAINE LLC (2020). Available at: https://www.trouwnutrition.ua/ (Accessed 14 January 2020).

4. The Electronic Archive of Igor Sikorsky Kyiv Polytechnic Institute (2019). "Vybir stratehiyi rozvytku zovnishn'oekonomichnoyi diyal'nosti pidpryyemstva". Available at: https://ela.kpi.ua/bitstream/123456789/29167/2/Liutenko_bakalavr.pdf (Accessed 14 January 2020).

5. Ukragrokonsalt (2019). "Analiz ahrarnykh rynkiv". Available at: http://www.ukragroconsult.com/ (Accessed 14 January 2020).

6. Latifundist (2014). "Top 8 vyrobnykiv kombikormiv v Ukrayini". Available at: http://latifundist.com/novosti/22186-top-8-proizvoditelej-kombikormov-v-ukraine (Accessed 14 January 2020).

7. The Embassy of Ukraine in the State of Israel. Available at: https://israel.mfa.gov.ua (Accessed 14 January 2020).

8. The Ministry of Economic Development and Trade. Available at: http://www.me.gov.ua/ (Accessed 14 January 2020).

УДК: 314.327 (338)

JEL classification: $\mathrm{F} 22$, F42

Марцинюк М.П.

канд. іст. наук, головний консультант ORCID ID: 0000-0002-4406-9056

Національний інститут стратегічних досліджень

\title{
УПРАВЛІННЯ МІГРАЦІЙНИМИ ПРОЦЕСАМИ В УМОВАХ ПАНДЕМІЇ COVID-19: ІНСТРУМЕНТИ, ЗАПРОВАДЖЕНІ МЗС УКРАЇНИ
}

\section{MANAGING MIGRATION PROCESSES IN THE FRAMEWORK OF THE COVID-19: TOOLS IMPLEMENTED BY THE MINISTRY OF FOREIGN AFFAIRS OF UKRAINE}

У статті розглянуто мережеві програми сочіальної допомоги, які були запроваджені Міністерством закордонних справ Украӥни для допомоги українським громадянам, які «застрягли» за кордоном під час розповсюдження пандемії COVID-19. Метою даної статті є здійснення системного аналізу роботи МЗС України з українськими громадянами та украӥнськими мігрантами за кордоном, зокрема висвітлення роботи програм, запроваджених зовнішньополітичним відомством під час поширення COVID-19 та їх впливу на управління міграчійними прочесами в умовах пандемії. Методологічною основою дослідження є системний підхід, принципи логічності та багатофакторності, а також сукупність загальнонаукових та спеціальних методів дослідження. Для виконання поставлених завдань було використано такі методи як: порівняльний, системний, проблемно-хронологічний, описово-оповідальний, структурнофункиіональний аналіз, критика джерел. Поєднання ичих наукових методів дало можливість: усебічно і комплексно дослідити роботу програм, запроваджених зовнішньополітичним відомством під час поширення COVID-19; відобразити їх взаємодію у роботі з украӥнськими громадянами та мігрантами за кордоном як 
частини комплексного процесу управляння міграційними процесами; показати значення окремої інституиії у системі державних структур роботи з мігрантами. В результаті дослідження виявлено, щзо в умовах пандемії коронавірусу COVID-19 система роботи Міністерства закордонних справ України по роботі 3 українськими громадянами за кордоном виявила свою високу ефективність, динамічність розвитку та адаптивність до ситуації, що швидко змінюється. Автор дійшов висновку, що система є ефективною, динамічною і інноваційною та в перспективі може бути використана для постійної роботи з украйнськими мігрантами. Автор наголошує на важливості забезпечення фінансування навчання консульських співробітників та співробітників причетних центральних органів виконавчої влади сучасним методам сочіальної роботи із мігрантами, із залученням украӥнських та зарубіжних соціологів, психологів, міграціологів.

Ключові слова: міграційні процеси, міграційна політика, зовнішня політика, МЗС України, пандемія COVID-19.

The subject of the study is the network of social assistance programs implemented by the Ministry of Foreign Affairs of Ukraine to help Ukrainian citizens who are "stuck" abroad due to restrictions that have been imposed to localize the spread of COVID-19. The purpose of this article is to analyze the work of the Ministry of Foreign Affairs of Ukraine with Ukrainian citizens and Ukrainian migrants abroad, including a range of programs implemented by the Foreign Ministry and their impact on migration management during the spread of COVID-19. The methodological basis of the study is a systematic approach, the principles of logic and multifactoriality, as well as a set of general and special research methods. To perform the tasks, were used the following methods: comparative, systemic, problem-chronological, descriptive-narrative, structural-functional analysis, critique of sources. These scientific methods allowed studying the work of ministerial programs as a part of a comprehensive process of managing migration processes, reflect their efficiency in working with Ukrainian citizens and migrants abroad; show the importance of a particular governmental institution in the system of state structures for working with migrants. The study examines constructed network of a social assistance programs, which help Ukrainian citizens who are "stuck" abroad during the spread of the COVID-19 and the main forms of interaction of the Ministry with Ukrainian citizens abroad. The author of the article make emphasis on the effectiveness of the implementation of network programs; give recommendations on their possible adaptation. The study revealed that in the context of the COVID-19 coronavirus pandemic, the system of work of the Ministry of Foreign Affairs of Ukraine with Ukrainian citizens abroad has shown its high efficiency, dynamic development and adaptability to the rapidly changing situation. The author concluded that the system is dynamic and innovative and could be effectively used working with Ukrainian migrants abroad. The author emphasizes the importance of funding for training of consular officers and employees of the central executive bodies involved in modern methods of social work with migrants, with the involvement of Ukrainian and foreign sociologists, psychologists, and migration scientists.

Keywords: migration processes, migration policy, foreign policy, Ministry of Foreign Affairs of Ukraine, COVID-19. 
Вступ. Широкий контекст пандемії COVID-19 створив рушії для розвитку інструментів поширення «позитивної вірусності» у іміджі Української держави, зокрема у іiї роботі з українськими громадянами та трудовими мігрантами за кордоном.

Одними 3 них стали передові технології соціальних мереж, що були використані МЗС України для здійснення ефективної комунікації 3 українськими громадянами за кордоном. Широке охоплення громадськості забезпечувалося інструментами соціальної мережі Facebook (програма «Захист») [1], платформами обміну повідомленнями Twitter i Telegram (телеграм-канал «Коронавірусінфо») [2], іншими мережевими ресурсами (проект «ДРУГ») [3].

Багатофункціональність соціальних мереж і платформ щодо структурування комунікативного простору дозволило МЗС України забезпечити оперативне інформування української громадськості за кордоном щодо поточної ситуації у зв'язку з COVID-19 та можливості отримати невідкладну допомогу.

Запроваджені Міністерством мережеві програми соціальної допомоги українським громадянам за кордоном та їхнім сім'ями показали свою ефективність, адаптивність і динамічність.

Зважаючи на те, що пандемія коронавірусу далека від завершення та зважаючи на необхідність забезпечення формування постійного доступного та оперативного зворотного зв'язку між Українською державою та іï громадянами за кордоном, створені МЗС мережеві програми мають розвиватися і отримувати підтримку.

У вітчизняній історіографії дослідженням міграційної політики присвячені роботи О. Малиновської, А. Надточія, А. Зубика, I. Темірової. До групи науковців, які досліджують міграційні процеси та українських мігрантів у контексті вивчення закордонного українства та української діаспори належать А. Зубик, Ю. Макар, В. Макар, А. Попок, В. Трощинський. Проблематику соціально-політичної інтеграції мігрантів, міграційних процесів у Європі та європейських демократичних цінностей досліджували О. Власюк, І. Гнибіденко, В. Копійка, О. Кислицина, А. Кудряченко, Ю. Макар, Е. Лібанова, О. Пархомчук, С. Пирожков, М. Романюк, В. Ціватий. Українські науковці зосереджувалися переважно на загальних тенденціях у міграційних процесах на території Свропейського Союзу чи пов'язаних з ними питаннях соціального розвитку, у той час як міграційна політика під час розповсюдження пандемії COVID-19 є актуальною і новою темою для наукових досліджень.

Постановка завдання. Метою статті $є$ аналіз роботи мережевих програм соціальної допомоги, які були запроваджені МЗС України для допомоги українським громадянам, які «застрягли» за кордоном під час розповсюдження пандемії COVID-19. Виокремити основні форми 
взаємодії міністерства 3 українськими громадянами за кордоном у соціальних мережах. Наголошується на ефективності запровадження таких мережевих програм, пропонуються рекомендації щодо їх можливої адаптації для роботи з українськими мігрантами.

Серед завдань дослідження відобразити взаємодію запроваджених зовнішньополітичним відомством програм у роботі 3 українськими громадянами та мігрантами за кордоном як частини комплексного процесу управляння міграційними процесам, а також показати значення окремої інституції у системі державних структур роботи з мігрантами.

Автором вперше здійснюється спроба комплексно дослідити роботу програм, запроваджених Міністерством закордонних справ України під час поширення COVID-19, для роботи 3 українськими громадянами та українськими мігрантами, які «застрягли» закордоном.

Методологія. В дослідженні використані такі методи: порівняльний, системний, проблемно-хронологічний, описовооповідальний, структурно-функціональний аналіз, критика джерел.

Результати дослідження. В умовах пандемії коронавірусу COVID-19 система роботи Міністерства закордонних справ України по роботі з українськими громадянами за кордоном показала свою високу ефективність, динамічність розвитку та адаптивність до ситуації, що швидко змінюється. Система $\epsilon$ ефективною, динамічною i інноваційною та в перспективі може бути використана для постійної роботи з українськими мігрантами.

Запроваджсеня програми «Захист» для громадян Украӥни, щцо «застрягли» за кордоном. В рамках програми використовуються методи групової роботи, що дозволяють не лише охопити велику кількість людей, а й надати допомогу окремим індивідам і групам, які опинилися в результаті переїзду (трудової чи «туристичної» міграції) в складній життєвій ситуації, організувати «віртуальне» i реальне середовище для надання необхідної допомоги. Відповідно до оперативних даних МЗС України станом на 14 квітня 2020 р. у програмі «Захист» [4] зареєструвалося 15 тисяч 849 громадян України.

У рамках програми «Захист» посольства та генеральні консульства України надають таку підтримку: вирішують питання прострочених документів/дозволів/віз на перебування в іноземній країні; співпрацюють з правоохоронними органами країни перебування для захисту законних інтересів громадян у разі їх порушення; інформують про можливість повернення до України, переміщення до сусідніх з Україною країн або ближче до України для подальшого повернення додому; інформують про зміни епідеміологічної ситуації в країні перебування, впровадження режимів надзвичайного стану тощо; консультують щодо вирішення побутових питань та охорони здоров’я 
(адреси та режим роботи продуктових магазинів, аптек, лікарень тощо); опрацьовують 3 місцевою владою та бізнесом, готовими допомагати, питання тимчасового розміщення у спеціально виділених місцях (кампусах, соціальних закладах, школах тощо) тих українських громадян, які не мають засобів для існування та місця проживання; налагоджують зв'язок українців, які вимушено залишаються на території іноземних держав і потребують допомоги, 3 громадськими організаціями та громадами українців, які готові допомагати.

Створення «віртуальних" спільнот та каналів у соціальних мережсах $\boldsymbol{i}$ месенджерах. Для полегшення комунікації, посольства та консульства України створили спеціальні спільноти та канали «Захист у (назва міста/країни)» у соціальних мережах i месенджерах, які працюють у країнах перебування українських громадян. У цих спільнотах налагоджують зв'язок українців, які вимушено залишаються на території іноземних держав і потребують допомоги, з громадськими організаціями та громадами українців, які готові допомагати.

Для прикладу, проаналізуємо механізми роботи програми «Захист» у Турецькій Республіці, де було створено три групи «Захист українців в Турецькій Республіці». Групи були створені трьома дипустановами України в Туреччині: Посольство України в Турецькій Республіці /Ukrayna Ankara Büyükelçiliği, Генеральне консульство України в Стамбулі /Ukrayna İstanbul Başkonsolosluğu, Консульство України в Анталії/Ukrayna Konsolosloğu Antalya, кожна з яких має свій консульський округ. Дипустанови закликали звертатися громадян України у групи за належністю турецької провінції до консульського округу. Також, для зручності українських громадян, на веб-ресурсах було розміщено списки провінцій, які належать до консульських округів. Станом на 14 квітня у групі "Захист українців у Турецькій Республіці" налічувалося 523 учасники, у групі "Захист українців у Туреччині (ГКУ в Стамбулі)" [5] - 463 учасники та у групі "Захист українців/ Консульство України в Анталії" [6] - 459 учасників. Загальна кількість учасників груп програми «Захист» у Туреччині нараховувала станом на вказану вище дату - 1445 осіб, серед них переважна більшість громадян України (передбачається, що до груп можуть належати i громадяни інших держав, які потребують допомоги). Показником орієнтованості на надання соціальної допомоги $\epsilon$ контрольні запитання для вступу до однієї із груп: «Ви потребуєте допомоги?» чи «Ви можете допомогти?».

Аналізуючи активність у вищезазначених групах, можна зробити висновок що в середньому у кожній із груп щоденно з'являється по 2-3 інформаційні пости від дипломатичної установи. Поза цим, 2-10 постів учасників групи 3 різними питаннями i потребами. В групах розміщується оперативна інформація щодо карантинних заходів у 
країні перебування, можливостей та засобів доправлення в Україну, процесу отримання необхідних дозволів, можливості безкоштовного отримання засобів захисту та інше. Консульські співробітники відповідають майже на кожне запитання, в багатьох випадках намагаючись зменшувати емоційну напругу, яка виникає під час обговорення публікацій деяких учасників. У цьому зв'язку гарною практикою можна вважати розміщення у групі «Захист українців/Консульство України в Анталії» інформації про надання допомоги психологом on-line.

Виходячи 3 аналізу роботи вищезазначених груп можемо констатувати, що громадяни України, що «застрягли» за кордоном, та їх сім'ї отримують конкретну кваліфіковану допомогу і підтримку, яка стала можливою лише за функціонування комплексу мереж територіальних дипломатичних установ, та мереж «віртуальних» дипломатичних установ в форматі груп «Захист», що враховують місцеву ситуацію і їі особливості.

Проект Добровільної реєстрації украӥнських громадян при подорожах за кордон - «ДРУГ». Оперативним інструментом у роботі 3 українськими громадянами за кордоном став запроваджений МЗС України у 2018 році проект «ДРУГ». «ДРУГ» - Добровільна реєстрація українських громадян при подорожах за кордон введена, як засіб попередження, за потреби - розшуку та надання сприяння громадянам України в разі надзвичайних подій за кордоном - природних катаклізмів, соціальних заворушень, військових конфліктів і показала свою ефективність у таких умовах. Побоювання українських громадян щодо iї «поліцейського» характеру не виправдались, а сама система стала допоміжним інструментом у роботі з українськими громадянами за кордоном під час карантинних заходів у зв'язку з пандемією COVID19. Проект «ДРУГ» працює у 8 регіонах майже у 200 країнах світу. Система реєстрації $є$ простою і доступною. Близько 10 тисяч українців, які зареєстрували свою подорож за кордон в системі «ДРУГ», а тепер «застрягли» за кордоном через пандемію, отримали повідомлення через мобільний додаток або на електронну пошту. Також до процесу оповіщення українських громадян за кордоном були залучені мобільні оператори.

Створення оперативного штабу та запуск телеграм-каналу «Коронавірус -інфо». Міністерство закордонних справ України створило оперативний штаб для координації роботи МЗС, причетних органів влади та міжнародних організацій з метою захисту громадян за кордоном і надання актуальної інформації щодо поширення Covid-19 у світі. Штаб створений 3 ініціативи та під головуванням міністра закордонних справ України. Головна мета оперативного штабу координація роботи МЗС з причетними органами влади в Україні та 
представництвами міжнародних організацій щодо надання допомоги громадянам України, які перебувають за кордоном на територіях, уражених коронавірусом. Ця мета, у свою чергу, передбачає також вчасне та достовірне інформування щодо розвитку ситуації у регіонах та країнах світу, поради щодо подорожей тощо.

Для інформування громадськості щодо заходів у зв'язку 3 пандемією COVID-19 MЗС України також запустило телеграм-канал «Коронавірус -інфо». Станом на 14.04.2020 на каналі 3655 підписників.

В умовах прогнозованої економічної рецесії, кількість українських громадян, які захочуть повернутися в Україну, у зв'язку із втратою робочих місць, буде збільшуватись, відбудуться друга і третя хвилі повернення. У цьому зв'язку, вважали б за доцільне надати доступ до соціальних груп системи «Захист» та проекту «ДРУГ» українським науковцям 3 метою здійснення аналізу кількісних даних, побудови перспективних моделей роботи з українськими громадянами за кордоном та в перспективі з українськими мігрантами за кордоном 3 метою їх реінтеграції.

Можливості адаптації запроваджених МЗС Украӥни програм для роботи з украӥнськими мігрантами. В перспективі, після завершення карантинних заходів, пов'язаних із розповсюдженням COVID-19, програма «Захист» може стати основою для роботи 3 українськими мігрантами із налагодженою системою соціальної взаємодії в рамках створених соціальних груп. Збереження і розвиток груп соціальних мереж програми «Захист» i їх перепрофілювання на роботу з мігрантами, може позитивно вплинути на розвиток міграційної політики України.

В подальшому, технологія соціальної роботи 3 громадянами України може бути перенесена на простійній основі на роботу 3 мігрантами, включаючи не лише допомогу окремим індивідам і групам, які опинилися в результаті міграції у складній життєвій ситуації, а й реорганізацію соціального середовища мігрантів, врахування міграційної ситуації, контролю міграційних потоків, чисельності мігрантів та заохочення їх до реінтеграції в Україну.

Для передачі досвіду організації та роботи груп соціальних мереж програми «Захист», навчання сучасним методам соціальної роботи 3 громадянами України за кордоном (українськими мігрантами), вважали б за доцільне передбачити відповідне фінансування для проведення тренінгів на базі Дипломатичної академії України співробітників МЗС України, ДПСУ, ДМС України, Міністерства соціальної політики України, Пенсійного фонду України, Державного центру зайнятості та інших органів державної влади, із залученням українських та зарубіжних соціологів, психологів, міграціологів. 
У разі перепрофілювання груп соціальних мереж програми «Захист» під роботу 3 українськими мігрантами, вважали б перспективним розглянути можливість введення посади «міграційного аташе» у закордонних дипломатичних установах України. «Міграційний аташе» міг би виконувати координуючу функцію, забезпечуючи зв'язок консульської установи із органами соціального захисту населення в України з метою реінтеграції українських мігрантів (працевлаштування, пенсійного забезпечення та отримання інших соціальних послуг). 3 цією метою до роботи в групах «Захист», у різних форматах, можуть бути залучені представники ДПСУ, ДМС України, Міністерства соціальної політики України, Пенсійного фонду України, Державного центру зайнятості та інших органів державної влади.

У посткарантинний період вважали б за доцільне розглянути можливість перетворення оперативного штабу в Координаційний центр по роботі з мігрантами на базі МЗС України, або створення такого координаційного центру по роботі з мігрантами на базі ДМС України, налагодження аналогічних каналам «Захист» каналів соціальних мереж по роботі з мігрантами із спільним доступом до них заінтересованих органів державної влади.

Після завершення карантинну телеграм-канал «Коронавірус інфо» може залишатися каналом роботи 3 мігрантами i бути перейменованим у канал «Мігрант -інфо». 3 метою стимулювання реінтеграції українських мігрантів, окрім розміщення інформації щодо можливості отримати допомогу у екстреній ситуації, також вбачається ефективним розміщення на каналі інформації про можливість працевлаштування, отримання та оформлення пенсій мігрантам, можливості придбання землі, із визначенням відповідальних за розміщення інформації департаментів у відповідальних органах державної влади. Окрім оперативного телеграм-каналу, важливо було б запустити уніфіковану платформу, на якій розмістити необхідні для мігрантів ресурси причетних ЦОВВ на зразок Порталу державних послуг «Дія» на pecypci https://diia.gov.ua/ [7].

Висновки. В умовах пандемії коронавірусу COVID-19 система роботи Міністерства закордонних справ України по роботі 3 українськими громадянами за кордоном виявила свою високу ефективність, динамічність розвитку та адаптивність до ситуації, що швидко змінюється. Система $\epsilon$ ефективною, динамічною i інноваційною та в перспективі може бути використана для постійної роботи з українськими мігрантами.

Запроваджені МЗС України програми допомоги українським громадянам, що «застрягли» за кордоном та їх сім'ями є актуальними, динамічними, мають розвиватися і отримувати підтримку. Засоби та 
методи соціальної роботи українських консулів з громадянами України, показують свою високу ефективність та можуть бути використані в подальшому для роботи з українськими мігрантами.

Для заохочення та допомоги у роботі існуючих програм МЗС України відзначається важливим надання доступу науковцям до системи «ДРУГ» та даних груп соціальних мереж програми «Захист», створених для допомоги українським громадянами за кордоном 3 метою здійснення аналізу кількісних даних, побудови перспективних моделей роботи 3 українськими мігрантами за кордоном та їх реінтеграції, а також популяризація системи Добровільної реєстрації українських громадян при подорожах за кордон «ДРУГ» на сайтах ЦОВВ України та сайтах організацій, що працюють 3 українськими мігрантами.

У разі використання системи програм МЗС України для роботи 3 мігрантами, вбачається перспективним:

- збереження програми «Захист» 3 подальшим іiі перепрофілюванням для роботи 3 українськими мігрантами, а також забезпеченням відповідного кадрового наповнення та бюджетного фінансування для роботи ії соціальних груп;

- збереження телеграм каналу МЗС України «Коронавірус-інфо» та перетворення його в подальшому на канал інформування українських мігрантів «Мігрант-інфо», створення єдиного інформаційного порталу для українських мігрантів;

- перетворення оперативного штабу для координації роботи МЗС України, причетних органів влади та міжнародних організацій з метою захисту громадян за кордоном і надання актуальної інформації щодо поширення Covid-19 у світі в Координаційний центр по роботі 3 мігрантами.

Важливо також забезпечити фінансування навчання консульських співробітників та співробітників причетних центральних органів виконавчої влади сучасним методам соціальної роботи із мігрантами, із залученням українських та зарубіжних соціологів, психологів, міграціологів.

1. Група "Захист україців у Турецькій Республіці". URL: https://www.facebook.com/groups/614470802730164/ (дата звернення: 14.04.2020).

2. Телеграм-канал «Коронавірус - інфо». URL: https://t.me/Ukraine_MFA (дата звернення: 14.04.2020).

3. Добровільна реєстрація українських громадян при подорожах за кордон «ДРУГ». URL: https://friend.mfa.gov.ua/\#/(дата звернення: 14.04.2020).

4. Звернення Міністра закордонних справ України Дмитра Кулеби до громадян за кордоном від 27 березня 2020 p. URL: https://mfa.gov.ua/news/zvernennya- 
ministra-zakordonnih-sprav-ukrayini-dmitra-kulebi-do-ukrayinciv-yaki-zalishayutsyaza-kordonom (дата звернення: 14.04.2020).

5. Група "Захист українців у Туреччині (ГКУ в Стамбулі)". URL: https://www.facebook.com/groups/UAinIST/?source_id=368919246466635 (дата звернення: 14.04.2020).

6. Група "Захист українців/ Консульство України в Анталії". URL: https://www.facebook.com/groups/214208363186823/?source_id=566641350435060 (дата звернення: 14.04.2020).

7. Портал державних послуг "Дія". URL: https://www.kmu.gov.ua/news/mincifrizapustilo-portal-derzhavnih-poslug-diya (дата звернення: 14.04.2020).

\section{References:}

1. Ministry of Foreign Affairs of Ukraine Group, (2020), "Protection of Ukrainians in the Republic of Turkey", Available at: https://www.facebook.com/groups/614470802730164/, (Accessed 14.04.2020).

2. Ministry of Foreign Affairs of Ukraine, (2020), "Telegram channel "Coronavirus info", Available at: https://t.me/Ukraine_MFA, (Accessed 14.04.2020).

3. Ministry of Foreign Affairs of Ukraine, (2020), Voluntary registration of Ukrainian citizens when traveling abroad - "FRIEND", Available at: https://friend.mfa.gov.ua/\#/, (Accessed 14.04.2020).

4. Ministry of Foreign Affairs of Ukraine, (2020), Address of the Minister for Foreign Affairs of Ukraine Dmytro Kuleba to citizens abroad dated March 27, Available at: https://mfa.gov.ua/news/zvernennya-ministra-zakordonnih-sprav-ukrayini-dmitrakulebi-do-ukrayinciv-yaki-zalishayutsya-za-kordonom, (Accessed 14.04.2020).

5. Ministry of Foreign Affairs of Ukraine, (2020), Group "Protection of Ukrainians in Turkey

(GKU in Istanbul)", Available at: https://www.facebook.com/groups/UAinIST/?source id=368919246466635, (Accessed 14.04.2020).

6. Ministry of Foreign Affairs of Ukraine, (2020), Group "Protection of Ukrainians / Consulate of Ukraine in Antalya", Available at: https://www.facebook.com/groups/214208363186823/?source_id=566641350435060, (Accessed 14.04.2020).

7. Government portal, (2020), Portal of public services "Diya", Available at: https://www.kmu.gov.ua/news/mincifri-zapustilo-portal-derzhanih-poslug-diya (Accessed 14.04.2020). 